ENTREPRENEURSHIP AND SUSTAINABILITY ISSUES

ISSN 2345-0282 (online) http://jssidoi.org/jesi/

2021 Volume 9 Number 2 (December)

http://doi.org/10.9770/jesi.2021.9.2(25)
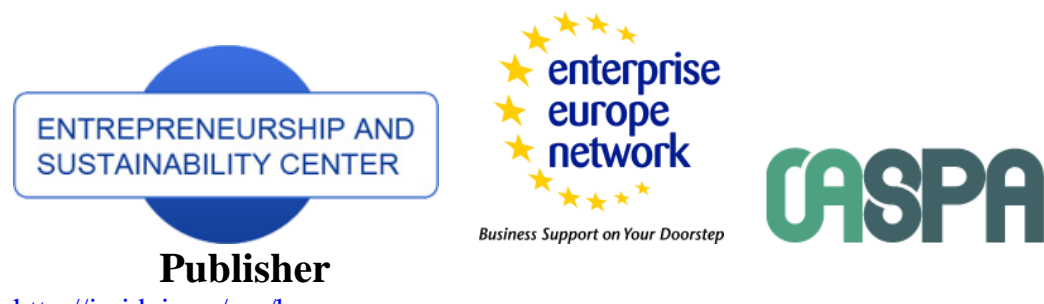

http://jssidoi.org/esc/home

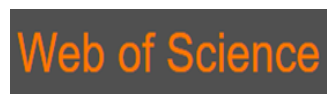

I) Clarivate

Analytics

\title{
FOREIGN DIRECT INVESTMENT AS A FACTOR OF TRADE DEVELOPMENT: CASES OF SELECTED COUNTRIES*
}

\author{
Halina Shmarlouskaya ${ }^{1}$, Natallia Shalupayeva ${ }^{2}$, Alina Danileviča ${ }^{3}$, Alina Betlej ${ }^{4}$, Ludmila Aleksejeva $^{5}$ \\ ${ }^{1}$ Belarus State Economic University, Partizanski Av. 26, Minsk, Belarus \\ ${ }^{2}$ Francisk Skorina Gomel State University, Sovetskaya Str. 104, Gomel, Belarus \\ ${ }^{3}$ Daugavpils University, Institute of Humanities and Social Sciences, Parades Str. 1-421, Daugavpils, LV-5401, Latvia \\ ${ }^{4}$ Institute of Sociological Sciences, John Paul II Catholic University of Lublin, Al. Ractawickie 14, 20-950 Lublin, Poland \\ ${ }^{5}$ Daugavpils University, Department of Economics, Parades Str. 1-232, Daugavpils, LV-5401, Latvia
}

E-mails: ${ }^{1}$ galina.shmarlovskaya@gmail.com $;{ }^{2}$ nshalupaeva@mail.ru $;{ }^{3}$ alina.danilevica@du.lv ; ${ }^{4}$ alina.betlej@kul.pl;

Received 10 August 2021; accepted 5 November 2021; published 30 December 2021

\begin{abstract}
The purpose of the article is to identify the specifics and common features of the foreign direct investment (FDI) impact on foreign trade development in the Visegrad Group countries (the Czech Republic, the Republic of Hungary, the Republic of Poland and the Slovak Republic), to determine trade-related effects of FDI in the economies and the factors that caused them, as well as to highlight key points of the policy of FDI-led export expansion. The methodological basis of the study is presented by the theories of FDI and capital transnationalization that affect the FDI and international trade nexus, as well as the global value chains (GVCs) theories. The information base for the study was the UNCTAD data on FDI stock, FDI flows, merchandise and services exports and imports of the Visegrad countries for the period 1995-2017, as well as the databases of WTO, Eurostat and Central statistical offices of the Visegrad countries. The paper adds to the understanding the FDI and foreign trade nexus in a recipient country. The quantitative and qualitative trade-related effects of FDI attracted into the Visegrad Group countries are determined and calculated, the factors caused them are revealed. Econometric assessments of the relationship between FDI and export-import operations in the studied economies are carried out, tools for forecasting the export effects of FDI are developed. Key points of the policy of FDI-led export expansion are highlighted.
\end{abstract}

Keywords: foreign direct investment; foreign trade; multinational enterprise; global value chains; Visegrad Group.

Reference to this paper should be made as follows: Shmarlouskaya. H., Shalupayeva, N., Danileviča, A., Betlej, A., Aleksejeva, L. 2021. Foreign direct investment as a factor of trade development: cases of selected countries. Entrepreneurship and Sustainability Issues, 9(2), 384-401. http://doi.org/10.9770/jesi.2021.9.2(25)

JEL Classifications: E60, F11, F21, F52, O39, O15, Z13

\footnotetext{
* The publishing of this article was supported by the project "Digital future of Societies and Economies of Central and Eastern Europe” of The John Paul II Catholic University of Lublin, Poland, and funds of Daugavpils University, Latvia.
} 


\section{ENTREPRENEURSHIP AND SUSTAINABILITY ISSUES}

ISSN 2345-0282 (online) http://jssidoi.org/jesi/

2021 Volume 9 Number 2 (December)

http://doi.org/10.9770/jesi.2021.9.2(25)

\section{Introduction}

Nowadays FDI is an important factor in foreign trade development in many countries of the world. According to UNCTAD, already at the edge of the XX-XXI centuries, China, Taiwan, Mexico, Republic of Korea, Costa Rica, Singapore, Thailand have succeeded in developing their export due to FDI. However, empirical studies do not lead to a conclusion about the uniquely positive impact of FDI on the host economies, including on their foreign trade. In this regard, it seems relevant to investigate the practical aspects of FDI trade-related effects formation, FDI impact on foreign trade dynamics and structure, export potential development in recipient countries.

In the article, the Visegrad Group countries (the Czech Republic, the Republic of Hungary, the Republic of Poland and the Slovak Republic) are selected to study the world experience of using FDI for foreign trade development. This choice is predetermined by two facts:

1) The Visegrad Group countries are a vivid example of the decisive role of multinational enterprises (MNEs) in expanding and changing the structure of a host country's foreign trade. So, UNCTAD research (UNCTAD, 2012) shows that according to the FDI Contribution Index among all countries of the world the largest contribution of FDI to the recipient economy development was registered in Hungary, followed by Belgium and Czechia. At the same time, all countries of the region represented in the ranking (the Czech Republic, the Republic of Hungary, the Republic of Poland) are leaders in the world by the FDI contribution to export development.

2) The experience of the Visegrad Group countries in using FDI for foreign trade development, can be adapted in developing economies and economies in transition, especially at the initial stages of the economic system transformation, when developing economic policies, especially investment, trade and industrial ones.

The methodological basis of the study is presented by the theories of FDI and capital transnationalization that affect the FDI and international trade nexus, as well as the global value chains (GVCs) theories. Some aspects of the relationship between FDI and international trade were studied in various concepts of FDI and transnational corporations, in the papers of such scientists as J. H. Dunning (Dunning 1981, 2001), S. Hirsch (Hirsch, 1976), K. Kojima, T. Ozawa, (Kojima \& Ozawa, 1984), J.R.Markusen (Markusen, 2000, 2002), T. Ozawa (Ozawa, 1992), A.M. Rugman (Rugman,1986), R.Vernon (Vernon, 1966), as well as in the papers of theorists of network economy and GVCs G. Gereffi (Gereffi, 2005), P. Gibbon (Gibbon, 2001), J. Humphrey, H. Schmitz (Humphrey, Schmitz, 2000), J.C. Jarillo (Jarillo, 1988), R.Kaplinsky (Kaplinsky, 2004), W. Powell (1991), H.B. Thorelli (Thorelli, 1986), etc.

The information base for the study was the UNCTAD data on FDI stock, FDI flows, merchandise and services exports and imports of the Visegrad countries for the period 1995-2017, as well as the databases of WTO, Eurostat and Central statistical offices of the Visegrad countries.

\section{Literature Review}

The most important issue and the main point of disagreement among scientists studying FDI-Trade nexus is the question of whether FDI and international trade represent complementary or alternative processes.

The internalization theory, formulated by P. Buckley, M. Casson (Buckley, Casson, 1976) and A. Rugman (Rugman, 1986), raises the issue of the FDI and international trade nexus. This concept was based on investigations of R. Coase (Coase, 1937) and E. Penrose (Penrose, 1956), and supposed that the most important motive for production transnationalization were the intention for internalization and advantages of internal operations over open market transactions.

The product life cycle theory (PLC theory), developed by R. Vernon (Vernon, 1966), clarifies the reasons of transition from export to production abroad. It is shown that FDI extends the product life. At the stages of standardization and maturity, in order to successfully compete in the market, a company has to find ways to reduce production costs, which can be done via FDI. 


\section{ENTREPRENEURSHIP AND SUSTAINABILITY ISSUES}

ISSN 2345-0282 (online) http://jssidoi.org/jesi/

2021 Volume 9 Number 2 (December)

http://doi.org/10.9770/jesi.2021.9.2(25)

R. Aliber in the currency-premium theory developed monetary and financial aspects of TNCs functioning and concluded that corporations of countries with a strong currency, when choosing the way of their advantages realizing in a country with a weak currency, would prefer FDI. R. Aliber stated that host countries with weaker currencies had a high potential to attract FDI owing to differences in the market capitalization rates (Aliber, 1970).

S. Hirsch asserted that FDI could be analyzed within the framework of the industrial organization models and the location theory (Hirsch, 1976). He deduced criteria for choosing between two internationalization strategies (FDI and exports) based on minimizing total costs.

J. H. Dunning in the eclectic theory of international production (OLI model) integrated the elements of the internalization theory, ownership advantage theory and FDI location theory. So, firms choose FDI (not exports) when three preconditions coincide: the company has ownership, location and internalization advantages simultaneously (Dunning, 2001).

K. Akamatsu investigated the phenomenon of industrial development in emerging economies (Akamatsu, 1962). He substantiated the three-phase development of industries in the flying geese paradigm (FGP). According to this model, in the first phase of the industry development the demand for goods is mainly satisfied by imports, in the second stage imports are reduced as import-substituting production is developing and in the third stage industry becomes exporting. T. Ozawa added an investment aspect to this paradigm and showed that FDI helped to reduce significantly the second phase of development (Ozawa, 1992).

One of the main models that links FDI and international trade is the macroeconomic model of K. Kojima, in which FDI is divided into pro-trade and anti-trade (Kojima, Ozawa, 1984). The distinctive feature of the FDI, stimulating international trade, is its realization for production of undifferentiated, low-tech products. At the same time anti-trade FDI is carried out in high-tech industries, in which investing countries have a comparative advantage, in order to capture foreign markets, which in the result leads to exports substitution and balance of payments problems in the home country.

B. Blonigen created the model of export and foreign production nexus, according to which TNCs via FDI transfer a part of their value chain to the recipient country. So, the international production promotes intra-company trade in semi-finished products between branches of TNCs located in different countries (Blonigen, 2001).

It should be noted that at the present stage of the economic thought development, the integration of GVCs theories into the theories of international trade is taking place. So, to define a new type of trade in GVCs, G. Grossman and E. Rossi-Hansberg proposed the "trade in tasks" concept instead of the "trade in goods" concept (Grossman and Rossi-Hansberg, 2008). R. Baldwin and A. S. Blinder also concluded that the trade in finished goods was largely replaced by trade in intermediate goods and services, which was also associated with GVCs development (Baldwin, Robert-Nicoud, 2014). Later R. Baldwin and F. Robert-Nicoud introduced a simple but flexible analytical framework in which both trade in goods and trade in tasks arised (Baldwin and Robert-Nicoud, 2014).

As for the literature on the Visegrad countries, there is extensive literature on FDI in the region. For example, investigations of such scientists as L. Darmo, M. Novák and J. Lisý (Darmo et al. 2020), B. Ramasamy and M. Yeung (Ramasamy, Yeung 2020), T. Bieliński, M. Markiewicz, E. Oziewicz (Bieliński, 2019), P. Misztal (Misztal, 2020), N. Becker and A. Cie'slik (Becker, Cie'slik, 2020), M. Pečarić, T. Kusanović, P. Jakovac (Jakovac, 2021), T. Christoforidis and C. Katrakilidis (Christoforidis, Katrakilidis, 2021), P. Trąpczyński, M. Gorynia, J. Nowak and R.Wolniak (Trąpczyński et al., 2019), K. Josifidis, N. Supic and N. Doroskov (Josifidis et al., 2020), T. Dorożyński, B. Dobrowolska and A. Kuna-Marszałek (Dorożyński et al., 2020), M. Ganić and M. Hrnjic (Ganić, Hrnjic, 2019), M. Gorynia, J. Nowak, P. Trąpczyński, R. Wolniak (Gorynia et al., 2019), Ș.C. Gherghina, L.N. Simionescu, Oana S. Hudea (Gherghina et al., 2019), M. Ganić, M.Hrnjić (Ganić, 2021), B. Setiawan, A. Saleem, R. Jeyakumar Nathan, Z. Zeman, R. Magda and J. Barczi (Setiawan et al., 2021) and others.

At the same time the literature on the relationship between FDI and trade in these countries is not so numerous. 


\section{ENTREPRENEURSHIP AND SUSTAINABILITY ISSUES}

ISSN 2345-0282 (online) http://jssidoi.org/jesi/

2021 Volume 9 Number 2 (December)

http://doi.org/10.9770/jesi.2021.9.2(25)

M. Weresa (Weresa, 2001) concluded that in Poland the main element of the FDI influence on trade is its contribution to export creation and restructuring. The changes in companies with foreign participation were of a different nature. They included a rise in foreign trade volume, profitability and changes in employment. The inflow of FDI did not substitute for Poland's trade with the EU. On the contrary, it created trade flows, as foreign investment was made mainly in sectors where Poland already had a comparative advantage in trade.

L. Kosekahyaoglu (Kosekahyaoglu, 2006) explored the relationship between FDI and trade flows for Turkey, the Czech Republic, Hungary and Poland. He concluded that the relationship between FDI and foreign trade in Poland is quite different than that of the Czech Republic and Hungary. The results suggested a bi-directional Granger causality relationship between FDI and foreign trade in the Czech Republic and Hungary, however, a unidirectional Granger causality between FDI and exports running from exports to FDI in Poland.

M. Sass, Z. Gál and B. Juhász (Sass, et al. 2018) analysed the impact of FDI on the host economies of the Visegrad countries in four selected service industries in two areas: export and employment. They concluded that FDI in the four selected service industries differ in terms of their vertical or horizontal nature: in business services FDI is predominantly vertical; in financial services and telecommunications it is predominantly horizontal; while in computer-related service activities both types can be found. The impact on the host economy differs in the four service industries. The authors found a positive and significant impact on exports in vertical business services and in horizontal telecommunications services. The positive impact either diminished or disappeared during the global recession of 2008-2009. The comparison of the four Visegrad countries demonstrates the heterogeneous intensity and significance of this impact, indicating their different specialisations in the analysed services industries.

C.T. Albulescu and D. Goyeau (Albulescu, Goyeau, 2019) assessed the CEE countries' intra-integration, focusing on the Czech Republic, Hungary, Poland and the Slovak Republic, and documented a complementarity effect between trade and FDI in these countries, which was stronger for historical trade partners.

A. Cieślik (Cieślik, 2009) studied empirically the relationship between the volume of trade and FDI in Poland. The author found that FDI contributes positively to the development of international trade between Poland and OECD countries, while the vertical model of the multinational firm may not be appropriate for explaining trade and FDI patterns between Poland and the OECD countries. Potential explanations can be such that even horizontal FDI may be trade creating if imported intermediate goods are used in the production process or alternatively FDI may be done with the aim of facilitating imports into the host country.

A. Cieślik and J. Hagemejer (Cieślik, Hagemejer, 2014) analysed export spillovers of multinational enterprises in Poland. The empirical results supported the existence of positive spillovers related to MNE export activity at the sectoral level but not at the regional level. Authors concluded also that the individual absorptive capacity determined the size of export spillovers.

A. Cieślik, A. Michalek, J.J. Michalek, J. Mycielski (Cieślik, et al. 2015) investigated the determinants of firms' export performance in three Baltic states and four Central European countries (the Czech Republic, Hungary, Poland and Slovakia). The results obtained for the Baltic and Visegrad countries indicated that the probability of exporting is positively related to the level of productivity, firm size, the share of university graduates in productive employment and the internationalization of firms.

A. Cieślik, J. Michałek, K. Szczygielski (Cieślik et al., 2019) used the negative binomial model to examine empirically the main reasons for multinational activity of firms originating from the new EU member states in Poland during the period 1990-2014. The estimated specification of the empirical model was based on the modified knowledge-capital model with two types of capital in which both horizontally- and vertically-integrated firms could coexist in equilibrium. The assembled empirical evidence pointed to both market access and efficiency seeking as the main reasons for undertaking foreign direct investment in Poland by multinational 


\section{ENTREPRENEURSHIP AND SUSTAINABILITY ISSUES}

ISSN 2345-0282 (online) http://jssidoi.org/jesi/

2021 Volume 9 Number 2 (December)

http://doi.org/10.9770/jesi.2021.9.2(25)

enterprises based in the new EU-12 member states. However, cultural proximity does not seem to be an important factor in explaining the extent of multinational activity in Poland.

A. Cieślik (Cieślik, 2020) pointed to the vertical motive as the primary reason for undertaking FDI in Poland in 1996-2015 by multinational firms based in the OECD member states. However, when the model was re-estimated for the pre-accession period only, both efficiency seeking and market seeking motives were important. Finally, the estimation results obtained for the post-accession years only revealed that the pure vertical model was preferred to both the pure horizontal model and the knowledge capital model. Moreover, it was found that the importance of the vertical reason for inward FDI in Poland has increased over time. This suggests the changing pattern of inward FDI in Poland due to its increased involvement into the GVCs organized by the MNEs from the source countries.

However, the scientific literature does not provide a comprehensive study of FDI and foreign trade nexus in some regions of the world, including in the Visegrad countries' economies. It has predetermined the purpose of the article that is to identify the specifics and common features of FDI and foreign trade nexus in the Visegrad Group countries, to determine FDI trade-related effects in the economies and the factors that caused them, as well as to highlight key points of the policy of FDI-led export expansion.

\section{Research results}

First of all, it seems appropriate to investigate the dynamics of FDI inflows into the economies of the Visegrad countries that to a certain extent characterizes the countries' potential in the development of foreign trade due to FDI inflows.

Since the early 1990s FDI inflows into the region have been characterized by high dynamics. At present the Visegrad countries account for more than $70 \%$ of all FDI accumulated in Central and Eastern Europe 2. As a result, Czechia, Slovakia and Hungary surpassed most of the European Union (EU) countries in terms of FDI stock relative to GDP (the average level in the EU is 46.7\%, in the world - 35\%) (table 1) (UNCTAD, 2017).

Table 1. FDI stock in the Visegrad Group countries (end of the year)

\begin{tabular}{|c|c|c|c|c|c|c|c|c|c|c|}
\hline \multirow[t]{2}{*}{ Country } & \multicolumn{5}{|c|}{ FDI stock, billion US dollars } & \multicolumn{5}{|c|}{ FDI stock to GDP, $\%$} \\
\hline & 1995 & 2000 & 2011 & 2017 & 2018 & 1995 & 2000 & 2011 & 2017 & 2018 \\
\hline Republic of Hungary & 11,3 & 23 & 84 & 90.6 & 88.7 & 24.3 & 48.3 & 60.6 & 64.8 & 57.0 \\
\hline Czech Republic & 7,4 & 22 & 125 & 156 & 155.0 & 12.3 & 35.1 & 52.9 & 72.3 & 64.1 \\
\hline Republic of Poland & 7,8 & 34 & 198 & 238.5 & 231.8 & 5.5 & 19.5 & 31.1 & 45.3 & 39.6 \\
\hline Slovak Republic & 1,3 & 5 & 51 & 55.8 & 57.1 & 6.5 & 33.7 & 52.9 & 58.4 & 53.6 \\
\hline
\end{tabular}

Source: authoring based on UNCTAD data (UNCTAD, n. d.)

Poland is the leader in FDI stock in the region. At the beginning of 2019 , its share amounted to $47.8 \%{ }^{3}$ of all FDI accumulated in the Visegrad Group countries. Traditionally, investors were attracted in the country by a large and growing market, in which in the early 90s demand exceeded supply. Czechia ranks the first in the region in terms of the FDI stock to GDP (64.1\%, compared to $39.6 \%$ in Poland). Hungary became the first country in the region to create favorable conditions for production cooperation with foreign investors, and FDI plays a significant role in its economy. So, at the beginning of 2019, in Hungary, the ratio of FDI stock to GDP was equal to $57.0 \%$. Slovakia began to import actively FDI only in the early 2000s. As a result, at the beginning of 2019, its share in

\footnotetext{
${ }^{2}$ Calculated by authors on the basis of UNCTAD data (UNCTAD, n. d.).
}

${ }^{3}$ Calculated by authors on the basis of UNCTAD data (UNCTAD, n. d.). 


\section{ENTREPRENEURSHIP AND SUSTAINABILITY ISSUES}

ISSN 2345-0282 (online) http://jssidoi.org/jesi/ 2021 Volume 9 Number 2 (December) http://doi.org/10.9770/jesi.2021.9.2(25)

the total FDI stock in the region amounted to only $10.6^{4}$. The study showed that, despite a large number of registered enterprises with foreign capital in the Visegrad countries, the most of FDI was made by MNEs, whose regional strategy is often associated with plans to rationalize production on a European scale. The MNEs contributed to the formation of industrial clusters in the region, primarily of automotive one.

As a result, an important positive FDI effect in the economies was their rapid integration into the GVCs of MNEs. Intra-industry production cooperation developed in such areas as the automotive industry, the production of communications equipment and office electronics, furniture. The GVC participation index in the Visegrad countries exceeds both the average level of developing countries (48.6) and developed ones (48). According to the WTO-UNCTAD (WTO, n. d.), the highest degree of integration in international production is observed in Slovakia, where the GVC participation index is equal to 67.3\%, the lowest - in Poland (55.5\%) (WTO, n. d.).

So, it was the integration of the Visegrad countries' economies into GVCs (based on FDI inflows) that had a great influence on the development of their foreign trade, especially of their export. Due to the high level of international competitiveness, access to foreign distribution networks, MNEs took dominant positions in foreign trade of the region. For example, at the end of 2016, in Poland the share of enterprises with foreign capital accounted for $43.6 \%$ of merchandise and services exports and for $56.6 \%$ of imports ${ }^{5}$.

As a result, in the region the foreign trade turnover and the degree of participation in international labor division increased significantly (in 2017, the foreign trade turnover of Hungary was equal to 235 billion US dollars, Poland - 551, Slovakia- 178.8, Czechia - 327.5) (UNCTAD, n. d.), as well as the foreign trade balance of the studied economies improved (figure 1).

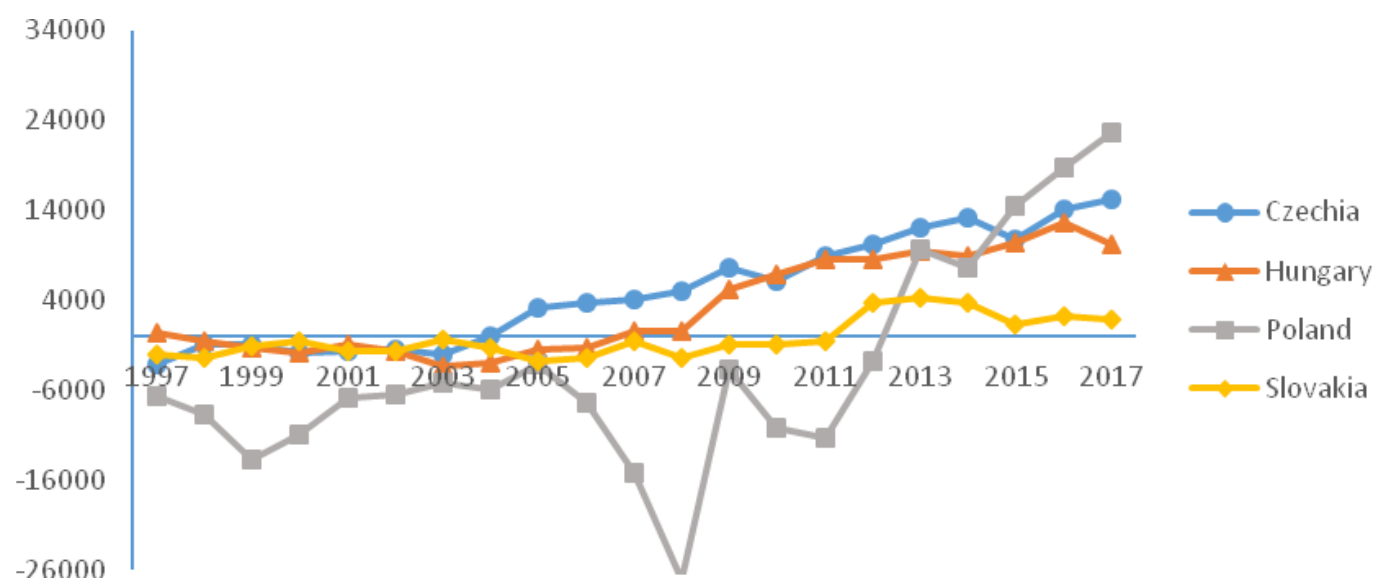

Figure 1. Foreign trade balance of the Visegrad countries (total trade in goods and services), million USD

Source: authoring based on UNCTAD data

To assess the degree and the nature of the FDI impact on the foreign trade development in the Visegrad countries, as well as to identify the quantitative trade-related effects of FDI, the FDI and foreign trade nexus in these countries was evaluated using econometric methods. It aimed to determining the form and the nature (alternative or complementary) of interrelation between the studied indicators.

The information base for the study was the UNCTAD data on FDI stock (X) and merchandise and services exports and imports (Y) of the Visegrad countries in 1995-2017. The choice of the FDI stock indicator for the

\footnotetext{
${ }^{4}$ Calculated by authors on the basis of UNCTAD data (UNCTAD, n. d.).

${ }^{5}$ Calculated by authors on the basis of Eurostat data.
} 
FDI evaluating is predetermined by the fact that in the result of theoretical and empirical analysis it was justified that FDI trade-related effects in a recipient country were dependent on the FDI stock in it (Shalupayeva, 2019).

The following scientific hypotheses were formulated.

Hypothesis 1. FDI stock is one of the major factors in export development in the Visegrad Group countries.

Hypothesis 2. FDI accumulation contributes to balancing the foreign trade of the Visegrad Group countries.

To confirm/disprove the hypotheses, paired econometric dependencies of exports and imports $\left(\mathrm{Y}_{\mathrm{t}}\right)$ on FDI stock $\left(X_{t}\right)$ for each of the countries have been analyzed (for details see (Kamornikov, Shalupayeva, 2019). The calculation was carried out using a data analysis package in MS Excel.

This analysis made it possible to substantiate a number of conclusions.

1) There is a noticeable positive interrelation between FDI stock and merchandise exports volume in the economies of Czechia, Hungary and Poland (for example see figure 2).

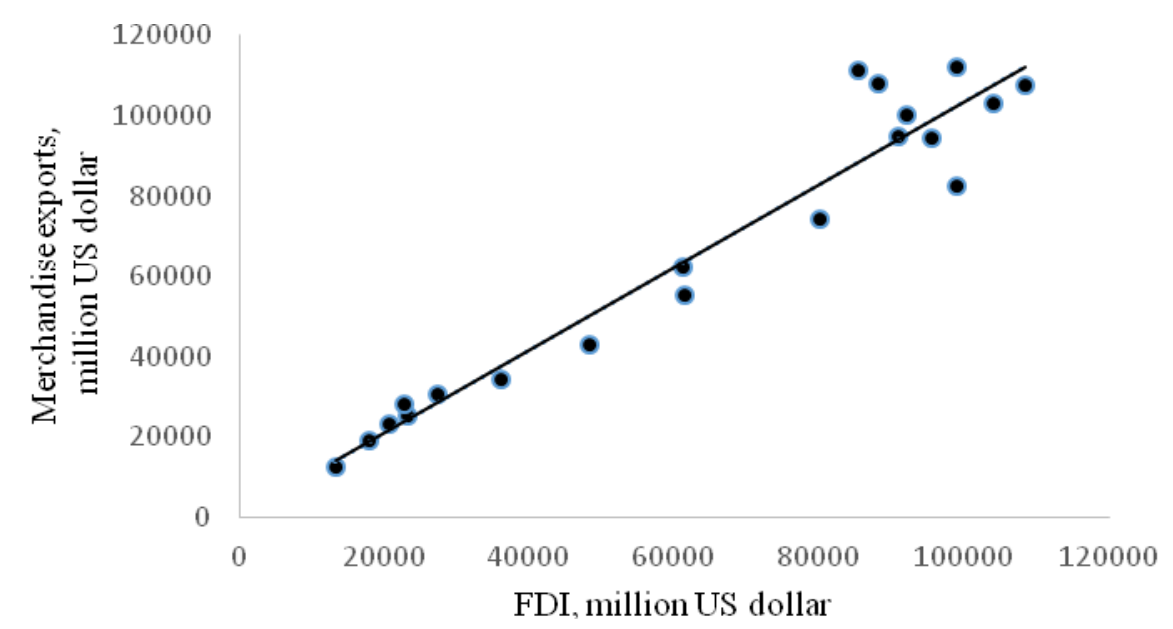

Figure 2. Correlation field of the dependence of merchandise exports on FDI stock in Hungary

Source: authoring based on UNCTAD data (UNCTAD, n. d.)

In the Slovak economy this interrelation is characterized as moderate (table 2).

2) FDI is a significant factor in the development of foreign trade in goods in all countries of the Visegrad Group. It determines the dynamics of Hungary's merchandise exports by 53\%, Czechia, Poland and Slovakia - by 44, 43 and $24 \%$, respectively (table 2 ).

3) The average elasticity coefficient of merchandise exports by FDI in all countries is less than 1 . The smallest elasticity coefficient is observed in Czechia (0.928), the largest - in Hungary, where the change in FDI by $1 \%$ leads to an increase in merchandise exports by $0.991 \%$ (table 2 ). 
Table 2. The results of the regression analysis of the FDI and merchandise exports interrelation in the Visegrad Group countries

\begin{tabular}{|l|c|c|c|}
\hline \multicolumn{1}{|c|}{ Country } & Correlation coefficient*, R & Determination coefficient*, ${ }^{2}$ & Elasticity coefficient, E \\
\hline Republic of Hungary & 0,731 & 0,534 & 0,991 \\
\hline Czech Republic & 0,663 & 0,440 & 0,928 \\
\hline Republic of Poland & 0,655 & 0,429 & 0,949 \\
\hline Slovak Republic & 0,492 & 0,242 & 0,966 \\
\hline
\end{tabular}

* After removing trends in the model

Source: authoring based on UNCTAD data (UNCTAD, n. d.)

4) The quantitative export effects of FDI in all countries of the region exceed import effects. The largest export effect is observed in Slovakia (1,517 US dollars per 1 dollar of FDI), the smallest - in Poland (1,114 US dollars per 1 dollar of FDI) (table 3).

Table 3. Quantitative trade-related effects of FDI in the economies of the Visegrad Group countries, USD per 1dollar of FDI

\begin{tabular}{|l|c|c|c|c|c|c|}
\hline \multirow{2}{*}{ Country } & \multicolumn{3}{|c|}{ Export effects } & \multicolumn{3}{c|}{ Import effects } \\
\cline { 2 - 7 } & Goods & Services & $\begin{array}{c}\text { Goods and } \\
\text { services }\end{array}$ & Goods & Services & $\begin{array}{c}\text { Goods and } \\
\text { services }\end{array}$ \\
\hline Republic of Hungary & 1,062 & 0,206 & 1,268 & 0,947 & 0,167 & 1,114 \\
\hline Czech Republic & 1,143 & 0,150 & 1,293 & 0,989 & 0,126 & 1,115 \\
\hline Republic of Poland & 0,942 & 0,202 & 1,144 & 0,906 & 0,149 & 1,055 \\
\hline Slovak Republic & 1,388 & 0,129 & 1,517 & 1,328 & 0,133 & 1,461 \\
\hline
\end{tabular}

Source: authoring based on UNCTAD data (UNCTAD, n. d.)

Thus, the results of econometric assessments allowed to confirm:

1) the hypothesis that FDI stock is one of the major factors in export development in the Visegrad Group countries;

2) the hypothesis that FDI accumulation contributes to balancing the foreign trade of the considered economies.

The results of econometric assessments made it possible also to determine the tools for forecasting the foreign trade development in the Visegrad Group countries. In particular, for the Hungarian economy the following regression equation of merchandise exports (EXP) dependence on FDI was obtained:

$$
\mathrm{EXP}=1,056 \mathrm{FDI}+973.01+\varepsilon
$$

So, the research identified the following trade-related effects of FDI in the Visegrad Group countries.

1) Quantitative export effects of FDI.

FDI is one of the most important factor in the export development in most countries of the region (table 2). Adaptation of enterprises acquired by foreign investors to the requirements of the world market and especially the construction of new enterprises integrated into the GVCs of MNEs ensured the growth of merchandise exports in 


\section{ENTREPRENEURSHIP AND SUSTAINABILITY ISSUES}

ISSN 2345-0282 (online) http://jssidoi.org/jesi/

2021 Volume 9 Number 2 (December)

http://doi.org/10.9770/jesi.2021.9.2(25)

the region. The quantitative export effects of FDI exceed import effects in all the Visegrad Group countries and it contributes to balancing their foreign trade (table 3).

Hungary has achieved significant success in developing its exports due to FDI inflows. So, at the end of 2016, in Hungary, the exports of the companies with foreign capital amounted to $72 \%$ of the total Hungarian exports (for comparison in Poland- $57.5 \%{ }^{6}$ ) (table 4).

Table 4. Trade indicators of the foreign-owned enterprises in Hungary, 2013-2016, billion HUF

\begin{tabular}{|l|c|c|c|c|}
\hline Indicators & 2013 & 2014 & 2015 & 2016 \\
\hline Exports & 18465,0 & 18786,4 & 23621,9 & 24646,0 \\
\hline Imports & 16139,3 & 18068,4 & 20460,1 & 20943,1 \\
\hline Foreign trade balance & 2325,7 & 718,0 & 3161,8 & 3702,9 \\
\hline
\end{tabular}

Source: authoring based on the Hungarian Central Statistical Office data.

Moreover, in Hungary, this group of enterprises is characterized by a positive balance of foreign trade, which in the 1990s - early 2000s contributed to maintaining a relatively low trade deficit, and later - to formation of a positive foreign trade balance. For example, according to UNCTAD, in 1998, Hungary's trade balance deficit was only 0.554 billion US dollars, compared with 8.6 billion in Poland.

In Poland, FDI inflows also create a significant impetus for export increasing. In 1995, exports of the companies with foreign capital amounted to $30 \%$ of the total country's exports, by the end of 2016 - already $57.5 \%{ }^{7}$ (table 5).

Table 5. Indicators of foreign trade in goods and services of the foreign-owned enterprises in Poland, 2007-2016, billion PLN

\begin{tabular}{|l|l|l|l|l|l|l|l|l|l|l|}
\hline Indicators & 2007 & 2008 & 2009 & 2010 & 2011 & 2012 & 2013 & 2014 & 2015 & 2016 \\
\hline Exports & 245,3 & 251,0 & 259,1 & 293,0 & 338,7 & 358,6 & 375,6 & 398,5 & 429,1 & 476,4 \\
\hline Imports & 264,8 & 279,0 & 301,4 & 324,2 & 370,3 & 377,2 & 379,3 & 398,7 & 419,3 & 444,7 \\
\hline Foreign trade balance & $-19,5$ & -28 & $-42,3$ & $-31,2$ & $-31,6$ & $-18,6$ & $-3,7$ & $-0,2$ & 9,8 & 31,7 \\
\hline
\end{tabular}

Source: authoring based on the Central Statistical Office of Poland data.

As a result, in the last decade in Poland, active exports growth of the enterprises with foreign capital has led to reduction in their negative trade balance, which since 2015 has gained positive values (table 5). So, according to the data of the Central Statistical Office of Poland, at the end of 2016, the foreign trade balance of companies with foreign capital amounted to 31.7 billion zlotys, while in 2009 it was equal to -42.3 billion zlotys (table 5). It should be noted that intra-group exports in 2016 amounted to $32.6 \%$ of total exports of enterprises with foreign capital functioning in Poland (Central Statistical Office of Poland, 2017).

So, the comparison of the exports growth rate of companies with foreign capital in Poland with their imports growth rate shows the country's increasing ability to attract export-oriented FDI.

2) Quality export effects of FDI.

a) Changes in the export geographical structure. After joining the EU, the active integration policy in the investment sphere led to a deep trade integration of the Visegrad countries with Western European countries. MNEs contributed a lot to the reorientation of their trade to the EU countries. For example, in 2016, trade with the EU accounted for 79.8\% of Polish exports (Central Statistical Office of Poland, 2018). Moreover, the

\footnotetext{
${ }^{6}$ Calculated by authors on the basis of the Hungarian Central Statistical Office data, the Statistics Poland data.
}

${ }^{7}$ Calculated by authors on the basis of the Statistics Poland data. 


\section{ENTREPRENEURSHIP AND SUSTAINABILITY ISSUES}

ISSN 2345-0282 (online) http://jssidoi.org/jesi/

2021 Volume 9 Number 2 (December)

http://doi.org/10.9770/jesi.2021.9.2(25)

concentration of Polish exports on EU countries tends to increase. So, in 2012, this indicator was equal to $76.1 \%$ (Central Statistical Office of Poland, 2018). These processes made the Visegrad Group economies highly dependent on the EU economies.

b) Changes in the export commodity structure. The research showed that due to FDI inflows, there was a significant improvement in the export commodity structure of the Visegrad countries, primarily due to the increase in the share of high value-added goods (components and parts for electronic equipment, computers, cars, etc.). Already in 1999, the share of these goods in Hungary's exports to the EU accounted for 63\%, in Czechia $47 \%$, and in Poland - $32 \%$. In consumer goods exports to the EU market the share of new products with improved consumer properties that meet the EU standards and requirements has increased.

In general, there was a significant increase in the share of medium-high-technology and high- technology industries in the considered countries' exports.

The contribution of MNEs to the development of high-tech products exports in the countries of the region is explained not only by an initially higher level of technological development of foreign companies, but also by more intensive research and development in them. So, according to Eurostat, in the Visegrad Group countries the share of domestic R\&D expenditures at enterprises with foreign capital in their total volume in the country ranges from $45 \%$ in Poland to $78 \%$ in the Slovak Republic.

In the Slovak Republic, despite relatively small volumes of FDI stock, it can be noted a high concentration of foreign capital in the high-tech sector of the economy. So, in the high-tech manufacturing sector, companies with foreign capital provide about $95 \%$ of gross revenue, in the services sector - almost $60 \%{ }^{8}$.

c) Increasing monopolization of exports. So, the calculations show that in Hungary the export of enterprises with foreign capital is concentrated, unlike imports, mainly in the sector of large companies, and the monopolization of exports by large MNEs is only increasing (table 6).

Table 6. Indicators of the concentration of merchandise foreign trade in Hungary, \%

\begin{tabular}{|l|c|c|c|c|}
\hline & 2013 & 2014 & 2015 & 2016 \\
\hline Exports: & & & & \\
- 5 companies & 16,3 & 21,2 & 28,1 & 29,1 \\
- 10 companies & 27,2 & 29,5 & 35,4 & 36,9 \\
\hline Imports: & & & & \\
- 5 companies & 10,5 & 6,5 & 7,8 & 8,3 \\
- 10 companies & 16,2 & 12,5 & 13,2 & 14,1 \\
\hline
\end{tabular}

Source: authoring based on the Hungarian Central Statistical Office data (Hungarian Central Statistical Office, 2017a)

So, according to the Central Statistical Office of Hungary (Hungarian Central Statistical Office, 2017b), in 2016, 8,737 companies with foreign capital carried out foreign trade operations, and 7,860 of them were importers and only 5,507 were exporters (while, as noted above, a group of enterprises with foreign capital was characterized by a positive foreign trade balance this year). As a result, in Hungary, a significantly higher level of concentration of merchandise exports, compared with imports, is observed. So, in 2016, quite $30 \%$ of Hungarian exports were realized by only five companies (compared with $8 \%$ of imports) ${ }^{9}$.

\section{3) Quantitative import effects of FDI.}

The intensive FDI inflows were also one of the major reasons for dynamic imports development in the Visegrad Group countries (table 3). For example, in Poland, companies with foreign capital are not only the largest exporters, but also are the largest importers. So, at the end of 2016, their imports amounted to 444.7 billion zlotys

\footnotetext{
${ }^{8}$ Calculated by authors on the basis of the Statistical Office of the Republic of Slovakia data.

${ }^{9}$ Calculated by authors on the basis of the Hungarian Central Statistical Office data.
} 


\section{ENTREPRENEURSHIP AND SUSTAINABILITY ISSUES}

ISSN 2345-0282 (online) http://jssidoi.org/jesi/

2021 Volume 9 Number 2 (December)

http://doi.org/10.9770/jesi.2021.9.2(25)

(which was $6.1 \%$ higher than in 2015), or $56.6 \%^{10}$ of the country's total imports (table 5). At the same time, $24.1 \%$ of total imports accounted for intra-group imports (25.2\% a year earlier) (Central Statistical Office of Poland, 2017).

Poland has traditionally been distinguished by the inflows of FDI oriented on a large domestic market. As a result, the FDI inflows caused the growth of the passive trade balance of the country. So, in 2016, import operations in the country were carried out by 11,938 companies with foreign capital (48.2\% of all companies functioning in the country), export - by 11,239 enterprises (45.4\%). At the same time, $40.8 \%$ of imports of enterprises with foreign capital represented the imports of final goods for resale (Central Statistical Office of Poland, 2017).

It should be noted that small and medium companies with foreign capital, compared to large ones, are more oriented on the domestic market. So, in 2016, in the group of enterprises with the number of employees up to 50 people, 8,330 enterprises carried out import operations and only 7,657 - export ones. In the group of large enterprises with 250 employees and more, this gap is significantly smaller - 1,255 and 1,233 enterprises respectively (Central Statistical Office of Poland, 2017).

\section{4) Quality import effects of FDI.}

a) Changes in the import geographical structure. The FDI inflows of MNEs contributed to the increase in import concentration on the EU countries. So, in 2016, the trade with the EU accounted for $61.2 \%$ of Polish imports (Central Statistical Office of Poland, 2018). Moreover, the concentration of Polish imports on the EU countries tends to increase. So, in 2012, this indicator was equal to $57.5 \%$ (Central Statistical Office of Poland, 2018).

b) Changes in the import commodity structure. Due to the trade operations of MNEs the share of capital-intensive and high-tech products in the Visegrad Group countries imports increased while the share of fuel and raw materials decreased. Already in 1999, the share of equipment and vehicles in Hungarian imports amounted to $50 \%$, in Poland and Slovakia - to $38 \%$, in Czechia - to $40 \%$. The inflows of market-oriented FDI also stimulated the growth of high-quality consumer goods imports, primarily in Poland.

At the same time, the research revealed also a number of negative trade-related effects of FDI in the economies of the Visegrad Group countries:

- foreign trade activities of companies with foreign capital (which as a rule use imported materials, equipment and components more actively than domestic firms) negatively affected the balance of payments of the Visegrad Group countries in the case of FDI oriented to the domestic market (example of Poland);

- expansion of the export-oriented foreign sector made the economies of the region highly dependent on the external economic environment;

- reorientation of foreign trade to one main geographical direction (EU market) while losing positions in the markets of traditional partners, which made the economies of the Visegrad Group countries highly dependent on the European countries' economies (for example, in 2016, trade with the EU amounted to 79.8\% of Polish exports and $61.2 \%$ of imports);

- closure or reorganization for assemblies or simple components production of a number of enterprises purchased during the privatization process (examples of Polish companies Zamech, Dolmel, etc.);

- FDI concentration at $100 \%$ foreign-owned enterprises, poorly integrated into the national economy, which is due to the EU legislation that did not allow a selective approach to FDI (for example, in the Czech motor vehicle industry the Czech-owned companies are totally absent from the first tier suppliers and are only linked

\footnotetext{
${ }^{10}$ Calculated by authors on the basis of the Statistics Poland data (Central Statistical Office of Poland, 2017; Central Statistical Office of Poland, 2018).
} 


\section{ENTREPRENEURSHIP AND SUSTAINABILITY ISSUES}

ISSN 2345-0282 (online) http://jssidoi.org/jesi/

2021 Volume 9 Number 2 (December)

http://doi.org/10.9770/jesi.2021.9.2(25)

by casual technological relationships to foreign-owned multinational subsidiaries which has limited vertical spillovers of foreign-owned multinational subsidiaries on the indigenous industry) (Rugraff, 2010);

- growth of the national currencies real value (caused by FDI inflows and a decrease in economic risks for foreign investors), which in turn negatively affected the considered countries' exports;

- crowding out of domestic producers from entire segments of the economies, as a result economic growth in the region became highly dependent on the activities of the leading MNEs;

- relatively narrow production specialization of these countries, formed in accordance with the interests of MNEs, which made their economies more vulnerable during crisis.

As a result of the research, the factors that caused the mentioned trade-related effects of FDI in the Visegrad countries are revealed and divided into three groups.

1) Factors related to the motivation and strategies of MNEs. The main types of FDI attracted to the Visegrad countries are export-platform and complex FDI, which predetermined the significant role of MNEs in the export development of the studied economies. However, there are also inflows of market-oriented FDI in the region, aimed at satisfying domestic demand of the recipient countries, which are mainly characteristic of Poland. It may explain the fact that FDI in Poland caused the least export effects among all the countries of the region (table 3).

2) Factors related to the characteristics and economic potential of the host countries, including the countries' geographical position; unsaturated growing domestic markets; significant intellectual capital and research potential; relatively low cost of resources; agglomeration effect.

3) Factors related to economic policy of the host countries, including privatization processes; economic reforms that improved the investment climate; liberalization of investment and trade regimes; FDI incentive policies; creation of special economic zones; development of communication and financial infrastructure; involvement in the process of European integration and unification of national legislation with the European one.

The study of the Visegrad countries' experience highlighted key points of the policy of FDI-led export expansion.

1) Regional economic integration as a way to attract export-oriented FDI. Obviously, the joining the EU and the harmonization of national legislation with the European one, firstly, reduced investment risks in the Visegrad Group countries for foreign investors, and secondly, provided investors with additional benefits in the form of free trade in goods and services, free capital and labor movement within the intraregional market. The elimination of trade barriers with European countries has attracted the investment of East and Southeast Asia, Japan, seeking to expand exports to the EU market. The EU membership facilitated also the participation in GVCs, especially for the smaller firms in the CEE countries (Cieślik, Michałek and Szczygielski, 2019). As a result, the joining the EU increased the investment attractiveness of the countries of the region, which led to new export-oriented, in particular export-platform, FDI inflows and to profits reinvestment in these countries.

2) Integration into GVCs as an effective way to develop export due to FDI inflows. The integration of national producers in GVCs of transnational corporations was one of the main factors of exports development in the Visegrad group countries. Due to a high level of competitiveness and access to a foreign distribution network, branches of MNEs took dominant positions in the foreign trade of the countries. As a result, their foreign trade balance improved significantly.

3) Coherency of investment, trade and industrial policies. The success of the Visegrad Group countries in FDI attraction can be largely explained by the fact that their FDI policy, firstly, was a part of industrial policy and economic development policy as a whole, and secondly, was directed to achieving strategic goals, including foreign trade development. The methods and instruments of investment and trade policies used in these countries were well coordinated. For example, in the Czech Republic since 1998, investment incentives were dependent on the results of enterprises' economic activity. For example, one of the requirements was that investments should be 


\section{ENTREPRENEURSHIP AND SUSTAINABILITY ISSUES}

ISSN 2345-0282 (online) http://jssidoi.org/jesi/

2021 Volume 9 Number 2 (December)

http://doi.org/10.9770/jesi.2021.9.2(25)

made in the manufacturing sector, and at least $50 \%$ of the investment should be directed to the purchase of hightech equipment. In addition, government grants were provided for creation of new jobs (from 2,000 to 6,000 US dollars per person) and for training of employees (up to $35 \%$ of expenses).

4) Focus on large investment projects and targeted approach to strategic investors, which was especially evident in Hungary. Thus, most of the investment incentives in Hungary were provided by the tax system. For example, the full exemption from income tax for 10 years was provided for foreign companies if the investment was at least 33 million US dollars and at least 500 workers were employed. In Hungary, to attract large transnational corporations, free customs zones were also created in which the largest MNEs established their subsidiaries for assembling manufactured goods primarily for export. After joining the EU, Hungary had to abandon the practice of using these free customs zones as a tool for FDI attracting, but after 2004, for these purposes industrial parks harmonized with EU standards began functioning in the country.

5) Retention of the investment promotion system in new forms even after joining the EU, which has become possible due to the transformation of investment incentives. So, preferences began to be actively included into the employment policy, as well as the regional development and R\&D policies. For example, after joining the EU, in Hungarian export zones, they had to abandon differentiated tariffs for exported goods depending on the value added amount. Tariff protectionism, provided by the Czech Republic to Volkswagen group in exchange for large investment in Skoda, has also become impossible in EU. Nevertheless, the system of investment incentives in the Visegrad group countries has been preserved. For example, in Hungary, in order to stimulate research and development, the tax base might be reduced by the full amount of expenses on it.

6) Trade liberalization, primarily in the industries that are priority for the GVCs development. As the study showed, the trade liberalization is a key element in the strategy of attracting export-oriented FDI of MNEs in the context of GVCs development. In the Visegrad Group countries, trade liberalization has also become one of the main factors in increasing the attractiveness of their economies for FDI.

7) Active policy of increasing the potential of small and medium-sized enterprises as GVC participants, including by stimulating vertical economic relations between MNEs and local suppliers. So, in the Visegrad group countries different programs, grants and other financial instruments were used to support the investment of small and medium-sized enterprises, to develop relations between domestic suppliers and large foreign companies and MNEs. In Hungary, financial instruments have been used for delivering investments for Structural Funds since the 1994-1999 programming period (Nyikos, Soós, 2018). Their relative importance has increased during the programming period 2007-2013 and 2014-2020 as well.

8) Combination of human capital development policy with the development of legislation in the field of intellectual property rights protection in order to stimulate FDI inflows to the high-tech sector of the economy. In the Visegrad Group countries, relatively inexpensive and skilled workforce, along with increasing labor productivity, became an important factor stimulating the FDI inflows and the R\&D in the high-tech sector, that were further stimulated by harmonization of the countries' systems of intellectual property rights protection with the EU legislation.

\section{Conclusions}

It was justified that the integration of the Visegrad Group economies into the GVCs of MNEs, realized via FDI inflows, was the major factor in their foreign trade development, primarily, in the increase in their export potential and the transformation of their international specialization. It is the FDI of MNEs that became one of the main factors that ensured the creation of export-oriented and competitive companies in the automotive, electronic, chemical, food, tobacco industries in the considered countries. A special feature of the Visegrad Group countries is that their deep integration into the GVCs is realized mainly by imports of parts and components rather than raw 


\section{ENTREPRENEURSHIP AND SUSTAINABILITY ISSUES}

ISSN 2345-0282 (online) http://jssidoi.org/jesi/

2021 Volume 9 Number 2 (December)

http://doi.org/10.9770/jesi.2021.9.2(25)

materials, which ensures their participation in the final stages of international production process, rise of the value added created and development of high-tech exports.

Based on the results of econometric assessments, the hypothesis that there is a positive connection between FDI and merchandise exports in all Visegrad Group countries was confirmed. It is proved that FDI is an important factor in export development in all considered economies, determining the change in the volumes of Hungarian merchandise exports by 53\%, Czech, Polish and Slovak - by 44, 43 and $24 \%$ respectively. The quantitative traderelated effects of FDI in the Visegrad Group economies are calculated. It's justified that the quantitative export effects of FDI in all countries of the region are superior to import effects. The largest export effects per 1 US dollar of FDI are observed in Slovakia, the smallest - in Poland.

The trade-related effects of FDI revealed in the Visegrad Group countries are divided into quantitative (significant increase in commodity exports and an increase in imports) and qualitative (change in the export geographical structure due to the trade reorientation to EU countries and other developed countries; change in the export commodity structure, which is manifested in a radical decrease in the share of traditional labor-intensive products and an increase in the share of capital-intensive products; growth of the share and volumes of high-tech products exports, which was the result not only of an initially higher level of technological development of foreign companies, but also more intensive R\&D in them; change in the import geographical structure due to an increase in its concentration in the EU countries; change in the import commodity structure, which is manifested in an increase of the share of capital-intensive and high-tech products and a reduce in the share of fuel and raw materials). Both positive and negative trade-related effects of FDI in the economies of the Visegrad Group countries are identified, but it is justified that the positive macroeconomic trade-related effects of FDI exceed the negative ones. And it is shown that FDI inflows to the economies of the region have largely positively influenced both quantitative and qualitative indicators of their participation in international trade and contributed to transformation of their specialization in international labor division.

It is shown by the example of the Visegrad Group countries that a recipient country's ability to use FDI as a tool for export development depends, on the one hand, on the motivation and strategies of MNEs and, on the other hand, on the economic potential and policies of the host country. In general, an active policy of FDI attracting, an individual approach to investors, development of dynamic competitive advantages, as well as the economic integration with developed EU countries ensured a significant optimization of the process of integrating of the Visegrad Group countries into international production.

The study made it possible to highlight a number of key points of the policy of FDI-led export expansion, among them: regional economic integration as a way to attract export-oriented FDI; integration into GVCs as an effective way to develop export due to FDI inflows; focus on large investment projects, targeted approach to strategic investors; the investment promotion system based on the coherency of investment, trade and industrial policies; trade liberalization, primarily in the industries that are priority for the GVCs integration; active policy of increasing the potential of small and medium-sized enterprises as GVC participants; combination of human capital development policy with the development of legislation in the field of intellectual property rights protection. 


\section{ENTREPRENEURSHIP AND SUSTAINABILITY ISSUES}

ISSN 2345-0282 (online) http://jssidoi.org/jesi/

2021 Volume 9 Number 2 (December)

http://doi.org/10.9770/jesi.2021.9.2(25)

\section{References}

Akamatsu, K. (1962). A Historical Pattern of Economic Growth in Developing Countries. Journal of Developing Economies, Vol. 1, No 1, 3-25. http://doi.org/10.1111/j.1746-1049.1962.tb01020.x

Albulescu, C.T. and Goyeau, D. (2019). The interaction between trade and FDI: The CEECs experience. International Economics and Economic Policy, Vol. 16, 489-509, available at: https://doi.org/10.1007/s10368-019-00438-1 (accessed 26 May 2021).

Aliber, R.Z. (1970). A Theory of Direct Foreign Investment. The International Corporation.

Baldwin, R. and Robert-Nicoud, F. (2014). Trade-in-goods and Trade-in-tasks: An Integrating Framework. Journal of International Economics, Vol. 92, No. 1, 51-62.

Becker, N., Cieślik, A. (2020). Determinants of German Direct Investment in CEE Countries. Journal of Risk and Financial Management, Vol. 13, No 11, 268-285. https://doi.org/10.3390/jrfm13110268

Bieliński, T., Markiewicz, M. and Oziewicz, E. (2019). Do Central and Eastern Europe Countries Play a Role in the Belt and Road Initiative? The Case of Chinese OFDI into the CEE-16 Countries. Comparative Economic Research, No 22, 7-22. https://doi.org/10.2478/cer-2019-0009

Blonigen, B. A. (2001). In Search of Substitution between Foreign Production and Exports. Journal of International Economics, Vol. 53, No. 1, 81-104.

Buckley, P.J and Casson, M. (1976). The Future of the Multinational Enterprise. London: Macmillan.

Central Statistical Office of Poland. (2017). Economic Activity of Entities with Foreign Capital in 2016, available at: https://stat.gov.pl/en/topics/economic-activities-finances/activity-of-enterprises-activity-of-companies/economic-activity-of-entitieswith-foreign-capital-in-2016,2,11.html (accessed 26 June 2020).

Central Statistical Office of Poland. (2018). Yearbook of Foreign Trade Statistics of Poland 2017, available at: https://stat.gov.pl/en/topics/statistical-yearbooks/statistical-yearbooks/yearbook-of-foreign-trade-statistics-2017,9,11.html (accessed 21 July 2020).

Christoforidis, T., Katrakilidis, C. (2021). Does Foreign Direct Investment Matter for Environmental Degradation? Empirical Evidence from Central-Eastern European Countries. Journal of the Knowledge Economy. https://doi.org/10.1007/s13132-021-00820-y

Cieślik, A. (2009). Foreign direct investment and the volume of trade: the case of Poland. Economic Change and Restructuring, Vol. 42, 273-291. https://doi.org/10.1007/s10644-009-9072-x (accessed 26 May 2020).

Cieslik, A. (2019). What attracts multinational enterprises from the new EU member states to Poland? Eurasian Business Review, No 10, 117. https://doi.org/10.1007/s40821-019-00122-z

Cieślik, A. (2020). Determinants of foreign direct investment from OECD countries in Poland. Eurasian Economic Review, Vol. 10, 9-25, available at: https://doi.org/10.1007/s40822-019-00136-y (accessed 26 May 2021).

Cieslik, A. and Hagemejer, J. (2014). Multinational Enterprises, Absorptive Capacity and Export Spillovers: Evidence from Polish Firm's Level Data. Review of Development Economics, Vol. 18, Issue 4, 709-726, available at: http://dx.doi.org/10.1111/rode.12113

Cieslik, A., Michalek, A., Michalek, J.J. and Mycielski, J. (2015). Determinants of Export Performance: Comparison of Central European and Baltic Firms, Czech Journal of Economics and Finance (Finance a uver), Vol. 65, Issue 3, 211-229.

Cieślik, A., Michałek, J. and Szczygielski, K. (2019). What matters for firms' participation in Global Value Chains in Central and East European countries? Equilibrium. Quarterly Journal of Economics and Economic Policy, Vol. 14, Issue 3, 481-502. https://doi.org/10.24136/eq.2019.023 (accessed 26 May 2020).

Ciobanu, R., Şova, R., \& Popa, A.F. (2020). The Impact of FDI over Economic Growth and how COVID-19 Crisis Can Impact the CEE Economies. CECCAR Business Review, No 4, 64-72. http://dx.doi.org/10.37945/cbr.2020.04.08

Coase, R. H. (1937). The nature of the firm. Economica, Vol. 4, No 16, pp. 386-405.

Darmo, L., Novák, M. and Lisý, J. (2020). Relationship between Foreign Direct Investment Inflow and Unemployment in the Slovak Republic. Politická ekonomie, Vol. 68, No 4, 443-461. https://doi.org/10.18267/j.polek.1289

Dorożyński, T., Dobrowolska, B., \& Kuna-Marszałek, A. (2020). Institutional Quality in Central and East European Countries and Its Impact on FDI Inflow. Entrepreneurial Business and Economics Review, Vol. 8, No 1, 91-110. https://doi.org/10.15678/EBER.2020.080105

Dunning, J. H. (1981). The Eclectic Theory of International Production. Managerial and Decision Economics, Vol. 2, No. 12, $197-210$. 


\section{ENTREPRENEURSHIP AND SUSTAINABILITY ISSUES}

ISSN 2345-0282 (online) http://jssidoi.org/jesi/ 2021 Volume 9 Number 2 (December) http://doi.org/10.9770/jesi.2021.9.2(25)

Dunning, J. H. (2001). The Eclectic (OLI) Paradigm of International Production: Past, Present and Future. International Journal of the Economics of Business, Vol. 8, No. 2, 173-190. http://doi.org/10.1080/13571510110051441

Ganic, M. and Hrnjic, M. (2019). Does a country's business regulatory environment affect its attractiveness to FDI? Empirical evidence from Central and Southeast European countries. Eastern Journal of European Studies, Vol. 10, No 2, 89-105.

Ganić, M. and Hrnjić, M. (2021). How Does International Financial Integration Really Affect Post-Transition Countries' Growth? Empirical evidence from the CEE-10 countries. Journal of Central Banking Theory and Practice, No 3, 117-136. http://doi.org/10.2478/jcbtp-2021-0027

Gereffi, G. (2005). The Governance of Global Value Chains. Review of International Political Economy, Vol. 12, No. 1, $78-104$.

Gherghina, Ş.C., Simionescu, L.N. and Hudea, O.S. (2019). Exploring Foreign Direct Investment-Economic Growth Nexus-Empirical Evidence from Central and Eastern European Countries. Sustainability, Vol. 11, No 19, pp. 5421-5454. https://doi.org/10.3390/su11195421

Gibbon, P. (2001). Upgrading Primary Production: A Global Commodity Chain Approach. World Development, Vol. 29, No. 2, $345-363$.

Gorynia, M., Nowak, J., Trąpczyński, P. and Wolniak, R. (2019). Geographic patterns of Poland's FDI: the investment development path perspective. Post-Communist Economies, Vol. 31, No 4, 507-529. http://doi.org/10.1080/14631377.2019.1578581

Grossman, G.M. and Rossi-Hansberg, E. (2008). Trading Tasks: A Simple Theory of Offshoring. American Economic Review, Vol. 98, No. 5, 1978-1997.

Hirsch, S. (1976). An International Trade and Investment Theory of the Firm. Oxford Economic Papers, Vol. 28, No. 2, $258-270$.

Humphrey, J. and Schmitz, H. (2000). Governance and Upgrading: Linking Industrial Cluster and Global Value Chain Research, Working paper 120, IDS, Brighton, $37 \mathrm{p}$.

Hungarian Central Statistical Office. (2017a). Concentration of External Trade in Goods (2013-2016), available at: http://www.ksh.hu (accessed 15 June 2020).

Hungarian Central Statistical Office. (2017b). Number of Enterprises, Imports and Exports by Enterprise Size Class, Types of Enterprise and Owners (2013-2016), available at: http://www.ksh.hu (accessed 18 August 2020).

Jarillo, J.C. (1988). On Strategic Networks. Strategic Management Journal, Vol. 9, No. 1, 31-41.

Josifidis, K., Supic, N. and Doroskov, N. (2020). Foreign Direct Investment and Income Distribution: Evidence from Post-Communist New EU Member States. Eastern European Economics, No 58:6, 497-516. http://doi.org/10.1080/00128775.2020.1762496

Kamornikov, S. and Shalupayeva, N. (2019). Experimental Modeling of Merchandise Exports Dependence on the Foreign Direct Investment Attracted in the Republic of Belarus. Proceedings of Francisk Scorina Gomel State University, No. 2, $111-116$.

Kaplinsky, R. (2004). Spreading the Gains from Globalization: What Can Be Learned from Value-Chain Analysis? Problems of Economic Transition, Vol. 47, No. 2, 74-115.

Kojima, K. and Ozawa, T. (1984). Micro and Macroeconomic Models of Direct Foreign Investment: Towards a Synthesis. Hitotsubashi Journal of Economics, Vol. 25, No. 1, 1-20.

Kosekahyaoglu, L. (2006). A comparative analysis of FDI in Turkey and the CEECs: Is there any link between FDI and trade?. Journal of Business Economics and Management, Vol. 7, No. 4, 183-200, available at: https://doi.org/10.1080/16111699.2006.9636140 (accessed 26 May 2020).

Markusen, J.R. (2000). Foreign Direct Investment and Trade. University of Adelaide, Adelaide, 40 p.

Markusen, J.R. (2002). Multinational Firms and the Theory of International Trade. MIT Press, Boulder, 682 p.

Misztal, P. (2020). Foreign Direct Investment, Production Factors Productivity and Income Inequalities in Selected CEE Countries. TalTech Journal of European Studies, No 10, 146-172. https://doi.org/10.1515/bjes-2020-0008

National Bureau of Statistics of China. (2017). China Statistical Yearbook 2016, available at: http://www.stats.gov.cn/tjsj/ndsj/2016/indexeh.htm (accessed 15 June 2020).

Nyikos, G. and Soós, G. (2018). Public and Private Funds in National Economic Development in Hungary. Papers from the 26th NISPAcee Annual Conference, available at: https://www.researchgate.net/publication/329375407 Public and Private Funds in National Economic Development in Hungary (accessed 15 December 2020).

Ozawa, T. (1992). Foreign Direct Investment and Economic Development. Transnational Corporations, Vol. 1, No. 1, $27-54$. 


\section{ENTREPRENEURSHIP AND SUSTAINABILITY ISSUES}

ISSN 2345-0282 (online) http://jssidoi.org/jesi/

2021 Volume 9 Number 2 (December)

http://doi.org/10.9770/jesi.2021.9.2(25)

Pečarić, M, Kusanović, T, Jakovac, P. (2021). The Determinants of FDI Sectoral Structure in the Central and East European EU Countries. Economies, Vol. 9, No 2, 66-82. https://doi.org/10.3390/economies9020066

Penrose, E. T. (1956). Foreign investment and the growth of the firm. Economic Journal, Vol. 66, No 262, $220-235$.

Powell, W. (1991). Neither Market nor Hierarchy: Network Forms of Organization. SAGE Publications, London, 306 p.

Ramasamy, B. and Yeung, M. (2020). China's outward foreign direct investment (OFDI) to developing countries: the case of Central and Eastern Europe (CEE). Journal of the Asia Pacific Economy, https://doi.org/10.1080/13547860.2020.1790182

Rugman, A.M. (1986). New Theories of the Multinational Enterprise: An Assessment of Internalization Theory. Bulletin of Economic Research, Vol. 38, No. 2, 101-118.

Rugraff, E. (2010). FDI and Supplier-Oriented Upgrading in the Czech Motor Vehicle Industry. Regional Studies, Vol. 44, Issue 05, 627638.

Sass M., Gál, Z. and Juhász, B. (2018). The impact of FDI on host countries: the analysis of selected service industries in the Visegrad countries. Post-Communist Economies, Vol. 30, Issue 5, 652-674. https://doi.org/10.1080/14631377.2018.1445332

Setiawan, B., Saleem, A., Nathan, R.J., Zeman, Z., Magda, R. and Barczi J. (2021). Financial Market Development and Economic Growth: Evidence from ASEAN and CEE Region. Polish Journal of Management Studies, Vol. 23, No. 2, $481-494$. https://doi.org/10.17512/pjms.2021.23.2.29

Shalupayeva, N. (2019). Trade-related Effects of Foreign Direct Investment in Recipient Countries: Integrated Approach. Economy and Banks, No. 1, pp. 106-115.

Thorelli, H.B. (1986). Networks: Between Markets and Hierarchies. Strategic Management Journal, Vol. 7, No. 1, 37-51.

Trąpczyński, P., Gorynia, M., Nowak, J., Wolniak, R. (2019). EU Countries from Central and Eastern Europe, and the Investment Development Path Model: A New Assessment. Argumenta Oeconomica, No 2 (43), 385-406. https://doi.org/10.15611/aoe.2019.2.16

UNCTAD (2011). World Investment Report 2011: Non-equity Modes of International Production and Development, New York, Geneva, 226 p., available at: http://unctad.org/en/pages/PublicationWebflyer.aspx?publicationid=84 (accessed 18 August 2020).

UNCTAD (2017). World Investment Report 2017: Investment and the Digital Economy. New York, Geneva, 237 p., available at: http://unctad.org/en/pages/PublicationWebflyer.aspx?publicationid=1782 (accessed 18 August 2020).

UNCTAD (n. d.), UNCTAD Data Center, available at: http://unctadstat.unctad.org/wds/ReportFolders/reportFolders.aspx?sCS_ChosenLang=en (accessed 10 July 2020).

UNCTAD. (2012). World Investment Report 2012: Towards a New Generation of Investment Policies. New York, Geneva, 204 p., available at: http://unctad.org/en/pages/PublicationWebflyer.aspx?publicationid=171 (accessed 10 July 2020).

Vernon, R. (1966). International Investment and International Trade in the Product Life Cycle. Quarterly Journal of Economics, Vol. 80, No. 2, 190-207.

Weresa, M. (2001). The Impact of Foreign Direct Investment on Poland's Trade with the European Union. Post-Communist Economies, Vol. 13, No. 1, 71-83. https://doi.org/10.1080/14631370125114

WTO (n.d.). Trade in Value-added and Global Value Chains: Statistical Profiles, available at: https://www.wto.org/english/res e/statis e/miwi e/countryprofiles e.htm (accessed 15 June 2020).

\section{Ackowledgements}

The publishing of this article was supported by the project "Digital future of Societies and Economies of Central and Eastern Europe” of The John Paul II Catholic University of Lublin, Poland, and funds of Daugavpils University, Latvia. 


\section{ENTREPRENEURSHIP AND SUSTAINABILITY ISSUES}

ISSN 2345-0282 (online) http://jssidoi.org/jesi/ 2021 Volume 9 Number 2 (December)

http://doi.org/10.9770/jesi.2021.9.2(25)

Halina SHMARLOUSKAYA is Doctor hab. of Economics, Professor of the Department of International Business of the Faculty of International Economic Relations of the Belarus State Economic University. She is a member of Working Group on Investment Image for Foreign Investment Advisory Council (Belarus). She is a consultant for Ministry of Trade, Belarus, applied research projects, including Monitoring the Forms of trade in Belarus, Trade \& Logistics' Centers. Her research interests: international economics, international trade, TNC, networking economy, international investments and trade, economies in transition.

ORCID ID: https://orcid.org/0000-0001-9534-1251

Natallia SHALUPAYEVA is PhD in Economics, Associate Professor of the Department of World Economy and Economic Theory of the Faculty of Economics in Francisk Skorina Gomel State University. Her research interests: international production, international investment, international trade, multinational enterprises, networking economy, economies in transition.

ORCID ID: https://orcid.org/0000-0001-9069-5886

Alina DANILEVIČA is Dr.oec, Researcher at the Institute of Humanities and Social Sciences of Daugavpils University, Latvia. She has the status of Expert of the Latvian Council of Science in the fields of Economics and Entrepreneurship, Sociology and Social Work. She is Expert of Polish National Agency for Academic Exchange and Expert of the Foundation for Polish Science. Her research interests: regional economics, investments, sustainable development, investment climate (entrepreneurial environment).

ORCID ID: https://orcid.org/0000-0002-2749-2725

Alina BETLEJ is an assistant professor at the Institute of Sociological Sciences in the Faculty of Social Sciences of the John Paul II Catholic University of Lublin (Poland). She is an Expert of the Polish National Agency for Academic Exchange and The Polish Association for Technology Assessment. Her research interests: economic sociology, digital exclusion, sustainable development, ICT for ageing society, social innovations.

ORCID ID: https://orcid.org/0000-0002-2729-6564

Ludmila ALEKSEJEVA is PhD in Economics, associated professor, head of department of Economics at Daugavpils University (Latvia). Her research interests: regional economics, smart growth, social and economic aspects of multiple-helix. Since 2016 Expert of Latvian Council of Science in Economics and Entrepreneurship. She has more than 40 publications, 2 monographs.

ORCID ID: https://orcid.org/0000-0002-1965-0818

Make your research more visible, join the Twitter account of ENTREPRENEURSHIP AND SUSTAINABILITY ISSUES: @Entrepr69728810

Copyright (C) 2021 by author(s) and VsI Entrepreneurship and Sustainability Center

This work is licensed under the Creative Commons Attribution International License (CC BY).

http://creativecommons.org/licenses/by/4.0/

cC (†) Open Access 